\title{
PENGARUH LEVERAGE, STRUKTUR KEPEMILIKAN, DAN CORPORATE GOVERNANCE TERHADAP KEBIJAKAN DIVIDEN PADA SEKTOR MANUFAKTUR DI BEI
}

\author{
A A Istri Alit Urmila Dewi ${ }^{1}$ \\ Ida Bagus Anom Purbawangsa ${ }^{2}$ \\ ${ }^{1,2}$ Fakultas Ekonomi dan Bisnis Universitas Udayana, Bali, Indonesia \\ Email: udewi761@gmail.com
}

\begin{abstract}
ABSTRAK
Penelitian berikut mempunyai tujuan untuk menguji pengaruh leverage, struktur kepemilikan, serta corporate governance pada kebijakan dividen pada sektor manufaktur di BEI Periode 2012-2016. Penelitian ini dilaksanakan di semua perusahaan sektor manufaktur di Bursa Efek Indonesia (BEI). Banyaknya sample, dengan memakai metode purposive sampling ialah sebesar 18 perusahaan daripada 147 perusahaan selama periode 2012-2016. Teknik analisis data yang diterapkan didalam penelitian ini yaitu regresi linear berganda. Hasil analisis menjawab bahwasannya leverage secara parsial berpengaruh positif terhadap kebijakan dividen pada sektor manufaktur di Bursa Efek Indonesia Periode 2012-2016. Struktur kepemilikan secara parsial berpengaruh positif terhadap kebijakan dividen pada sektor manufaktur di Bursa Efek Indonesia Periode 2012-2016. Corporate governance secara parsial berpengaruh positif terhadap kebijakan dividen pada sektor manufaktur di Bursa Efek Indonesia Periode 2012-2016.
\end{abstract}

Kata kunci : leverage, struktur kepemilikan, corporate governance, kebijakan deviden

\begin{abstract}
This study aims to examine the effect of leverage, ownership structure, and corporate governance on dividend policy on manufacturing sector in Indonesia Stock Exchange Period 2012-2016. This research was conducted in all manufacturing companies in Indonesia Stock Exchange (BEI). The number of samples, using purposive sampling method is as many as 18 companies from 147 companies during the period 2012-2016. Data analysis technique applied in this research is multiple linear regression. The results of the analysis reply that leverage partially have a positive effect on the dividend policy in the manufacturing sector in Indonesia Stock Exchange Period 2012-2016. Partial ownership structure positively affects dividend policy in manufacturing sector in Indonesia Stock Exchange for 2012-2016 period. Corporate governance partially positively influences the dividend policy on the manufacturing sector in Indonesia Stock Exchange Period 2012-2016.
\end{abstract}

Keyword : leverage, ownership structure, corporate governance, dividend policy 


\section{PENDAHULUAN}

Semua organisasi mempunyai tujuan masing-masing yang mau tercapai. Tetapi, tujuan utama dari satu organisasi yaitu mendapat laba untuk organisasi itu. Laba itu bisa didapatkan daripada kegiatan operasional organisasi ataupun acara insiden organisasi. Agar mencapai tujuan organisasi, organisasi pun berharap bantuan modal dari pihak luar agar memberi dukungan kegiatan organisasi. Pihak luar yang disinggung yaitu pemberi kredit serta investor. Pihak luar itu, memberi harapan juga timbal balik dari organisasi. Dividen yang diserahkan oleh organisasi diharap investor sedangkan pemberi kredit lebih mengharapkan timbal balik berupa bunga (Anggie, 2013).

Kebijakan pembayaran dividen yang dilaksanalan oleh organisasi, dengan tersirat teratur didalam konflik keagenan diantara manajemen (agent) dengan pemegang saham (principal). Kebijakan pembayaran dividen adalah satu dari sekian keputusan vital yang dilaksanakan oleh organisasi, dikarenakan terkait dengan perencanaan pemakaian dana organisasi dimasa yang mendatang. Terlihat dari sisi pemberi dana, dividen adalah satu diantara beberapa faktor yang memberi pengaruh meningkatnya penyuntikan dana pada pasar saham. Pengimplementasian keputusan investasi sangatlah diberikan pengaruh oleh tersedianya dana organisasi yang memiliki asal daripada sumber dana didalam (internal financing) dan sumber dana diluar (external financing). Keputusan pemberian dana memiliki kaitan dengan menentukan struktur dana yang cocok untuk organisasi (Anuar dan Yakob, 2014). 
Leverage adalah salah satu faktor penting dalam unsur pendanaan. Perusahaan menggunakan operating dan financial leverage dengan tujuan agar keuntungan yang diperoleh lebih besar daripada biaya assets dan sumber dananya, dengan demikian akan meningkatkan keuntungan pemegang saham (Sartono, 2012:257). Leverrage bisa diberikan pemhaman untuk taksiran daripada resiko yang ada di sebuah organisasi. Hal berikut mempunyai arti bahwasannya, leverrage yang makin tinggi memberikan petunjuk resiko investasi yang makin tinggi juga. Organisasi dengan rasio leverage yang kecil mempunyai resiko leverage yang lebih rendah. Leverage perusahaan biasanya dinilai dengan memakai ratio keuangan yang diambil dari informasi akuntansi yang terdapat dalam laporan keuangan. Rasio leverage mengukur berapa besar penggunaan utang dalam pembelanjaan perusahan (Scott, 2003:20). Penelitian yang dilakukan oleh Osman dan Mohammed (2010) menemukan bahwa tingkat leverage berpengaruh negatif terhadap pola pembayaran dividen pada perusahaan sampel. Hasil penelitian yang sama dikemukakan oleh Muhammad (2015) yang menyatakan bahwa leverage dan dividen memiliki hubungan negatif.

Penelitian Mossadak dan Khemakhem (2015) mendapatkan bahwasannya hubungan negative serta signifikan diantara tingkat utang dengan kebijakan dividen. Hal tersebut tidak sesuai dengan riset yang dilaksanakan oleh Devi (2017) yang tak mendapatkan pengaruh signifiikan diantara leverrage dengan kebijakan dividen. Indah et al. (2010) menemukan pengaruh signifikan positif antara leverage dengan kebijakan dividen. Tina (2017) menyatakan pengaruh signifikan positif variabel leverage dengan kebijakan dividen. 
Kepemilikan saham bisa dibagi jadi kepemilikan manajerial, kepemilikan institusi serta kepemilikan minoritas. Tiap-tiap bentuk kepemilikan berikut dapat mempunyai kepentingan serta dampak yang beda pada $D P R$. Kepemilikan saham institusi serta kepemilikan manajerial adalah perkumpula yang memegang saham mayoritas. Pemegang saham terbanyak mempunyai fungsi melaksanakan kegiatan pengawasan pada prilaku manager yang condong memiliki sikap memberi untung dirinya sendiri. Struktur kepemilikan (owner structure) bisa membuat konflik keagenan yang berlangsung didalam organisasi (Brigham, 2011:87). Konflik berikut bisa kejadian diantara pemegang saham dengan manager, manager dengan kreditur, berbedanya urusan management dengan yang mempunyai saham. Hal yang berbeda tersebutlah yang bisa menyebabkan konflik didalam sebuah organisasi yang bisa dibilang konflik keagenan (agency conflict).

Hasil penelitian Kulathunga dan Azeez (2015) mengatakan bahwasannya hubungan diantara kepemilikan manajerial dengan kebijakan dividen dengan signifikan memiliki hubungan positif. Penelitian oleh Ikunda dan Kamau (2016) menyatakan bahwa struktur kepemilikan individu dan struktur kepemilikan institusional tidak memiliki hubungan signifikan terhadap dividend payout, serta terdapat korelasi positif antara struktur kepemilikan asing dan pembayaran dividen. Berbeda dengan Ballagobei dan Thiruchchenthurnathan (2016) menemukan bahwa ada hubungan negatif antara struktur kepemilikan manajerial dan pembayaran dividen. Penelitian Ekanayake dan Paranthaman (2015) kepemilikan manajerial berpengaruh positif dan signifikan terhadap kebijakan dividen di Indonesia. 
Teori keagenan menjelaskan bahwa dengan adanya corporate governance berfungsi sebagai alat untuk memberikan keyakinan kepada investor bahwa pemegang saham akan menerima return atas dana yang telah diinvestasikan. Good corporate governance merupakan struktur dan proses (Peraturan, Sistem dan Prosedur) untuk memastikan mengarahkan dan mengendalikan perusahaan untuk mewujudkan pertumbuhan berkelanjutan, meningkatkan nilai tambah dengan tetap memperhatikan keseimbangan kepentingan stakeholders yang sesuai dengan prinsip korporasi yang sehat dan peraturan perundang-undangan yang berlaku (Anggie, 2013). Indonesia, riset tentang pengaruh $G C G$ pada kebijakan dividen dilakukan oleh Anggie (2013). Ikunda (2016) menemukan bahwasannya GCG memiliki pengaruh positif dan signifikan pada kebijakan dividen.

Berdasarkan beberapa hasil penelitian sebelumnya dan adanya kontradiksi dan ketidaksamaan hasil dalam penelitian tersebut maka dibutuhkan penelitian lebih lanjut mengenai pengaruh leverage, struktur kepemilikan dan good corporate governance pada kebijakan dividen perusahaan manufaktur di BEI periode 20122016. Peneliti menggunakan perusahaan manufaktur dalam penelitian ini karena sektor manufaktur merupakan sektor terbesar di Indonesia serta memiliki badan usaha terbanyak, sehingga lebih diminati oleh investor untuk menanamkan sahamnya. Bertumbuhnya usaha industri manufaktur mempunyai tempat yang menonjol didalam berkembangnya ekonomi di negara kita dikarenakan memiliki hubungan langsung pada kemauan membeli rakyat sehari-harinya (Adnyana dan Badjra, 2014). 
Berdasarkan latar belakang di atas, dapat dinyatakan rumusan masalah seperti ini: 1) Apa leverage memiliki pengaruh signifikan pada kebijakan dividen di perusahaan manufaktur di Bursa Efek Indonesia periode 2012-2016? 2) Apa struktur kepemilikan memiliki pengaruh signifikan pada kebijakan dividen di perusahaan manufaktur pada Bursa Efek Indonesia periode 2012-2016? 3) Apa good corporate governance memiliki pengaruh signifikan pada kebijakan dividen di perusahaan manufaktur pada Bursa Efek Indonesia periode 2012-2016?

Meningkatnya utang dapat memberi pengaruh tinggi rendahnya keuntungan yang ada untuk para investor termasuk dividen yang dapat dikeluarkan. Sartono (2008:45) memberikan pernyataan bahwasannya Debt to Equity Ratio (DER) adalah ratio yang menunjukkan kemampuan perusahaan didalam melakukan semua kewajibannya, yang tercermin dari beberapa bagian modal sendiri yang dipakai dalam pembayaran utang. Menurut Brigham (2011) makin tinggi leverrage perusahan jadi cenderung agar melakukan pembayaran dividen mereka lebih kecil dengan tujuan agar memberi pengurangan rasa tergantung untuk permintaan secara eksternal. Hal ini membuat makin tingginya jumlah utang yang dipakai dalam struktur modal sebuah perusahaan, jadi dapat makin tinggi juga jumlah kewajibannya yang bisa memberi pengaruh tinggi rendahnya dividen yang bisa terbagi.

Mengutip hasil penelitian Osman dan Mohammed (2010) menemukan bahwa tingkat leverage berpengaruh negatif terhadap pola pembayaran dividen pada perusahaan sampel. Hasil penelitian yang sama dikemukakan oleh Muhammad (2015) yang menyatakan bahwa leverage dan dividen memiliki hubungan negatif. 
Penelitian Mossadak dan Khemakhem (2015) mendapatkan bahwasannya hubungan negatif serta signifikan diantara tingkat utang dengan kebijakan dividen. Hal berikut tidak sesuai dengan penelitian yang dilaksanakan oleh Devi (2017) yang tak mendapatkan pengaruh signifikan diantara leverage dengan kebijakan dividen. Indah et al. (2010) menemukan pengaruh signifikan positif antara leverage dengan kebijakan dividen. Tina (2017) menyatakan pengaruh signifikan positif variabel leverage dengan kebijakan dividen. Berdasar kepada kajian teori juga data empiris jadi dibuat rumusan hipotesis sebagai berikut:

$\mathrm{H}_{1}$ : Leverage berpengaruh negatif dan signifikan terhadap kebijakan dividen.

Struktur kepemilikan merupakan faktor yang berpengaruh pada kebijakan perusahaan. Salah satu kebijakan tersebut adalah kebijakan dividen. Hal tersebut memberi petunjuk makin tingginya persentase kepemilikan manajerial sebuah perusahaan jadi makin tinggi juga dividen yang terbagi untuk para pemegang saham dikarenakan makin tingginya persentase kepemilikan manajerial dapat membuat makin tinggi juga mampu atau tidaknya memperoleh keuntungan, hal ini dikarenakan selain manager itu melakukan pengelolaan saham investor, manager itu pula melakukan pengelolaan saham miliknya sendiri hingga dividen yang didapatkan para pemegang sahamnya pun besar (Devi, 2017).

Hasil penelitian Kulathunga dan Azeez (2015) memberi pernyataan bahwasannya hubungan diantara kepemilikan managerial dengan kebijakan dividen secara signifikan memiliki hubungan positif. Penelitian oleh Ikunda dan Kamau (2016) menyatakan bahwa struktur kepemilikan individu dan struktur kepemilikan institusional tidak memiliki hubungan signifikan terhadap dividend payout, serta 
terdapat korelasi positif antara struktur kepemilikan asing dan pembayaran dividen. Penelitian Ekanayake dan Paranthaman (2015) kepemilikan manajerial berpengaruh positif dan signifikan terhadap kebijakan dividen di Indonesia. Sedangkan kepemilikan institusional memiliki pengaruh positif dan signifikan dalam penelitian yang dilakukan oleh Ayu dan Vinola (2017). Berdasar kepada kajian teori serta data-data empiris jadi dibuat sebuah rumusan hipotesis sebagai berikut:

$\mathrm{H}_{2}$ : Struktur kepemilikan berpengaruh positif dan signifikan terhadap kebijakan dividen.

Agoes (2014) menyatakan bahwa tata kelola perusahaan bertujuan untuk melindungi kepentingan pemegang saham dengan mengurangi masalah keagenan dan oleh karena itu, kebijakan dividen menjadi aspek penting dari tata kelola perusahaan. Anggie (2013) melakukan pencatatan bahwasannya tata kelola perusahaan yang efisien dapat memberikan checks and balances antara manajer dan pemegang saham dan ini bisa membuat perusahaan untuk mengadopsi kebijakan dividen yang memaksimalkan kekayaan pemegang saham.

Hasil penelitian Ikunda (2016) menemukan bahwa good corporate governance memiliki pengaruh positif dan signifikan pada kebijakan dividen. Indah et al. (2010) dapat memberi sebuah bukti bahwasannya good corporate governance memiliki pengaruh positif pada kebijakan dividen. Putri (2018) memberi pernyataan bahwasannya variabel GCG memiliki pengaruh positif dan signifikan pada kebijakan dividen di dalam perusahaan. Tina (2017) membuktikan bahwasannya hal yang sama dimana variabel good corporate governance memiliki pengaruh positif signifikan terhadap kebijakan dividen. Berdasar kepada kajian 
teori serta data empiris jadi bisa dibuatkan perumusan hipotesa penelitian sebagai berikut :

$\mathrm{H}_{3}$ : corporate governance berpengaruh positif dan signifikan terhadap kebijakan dividen.

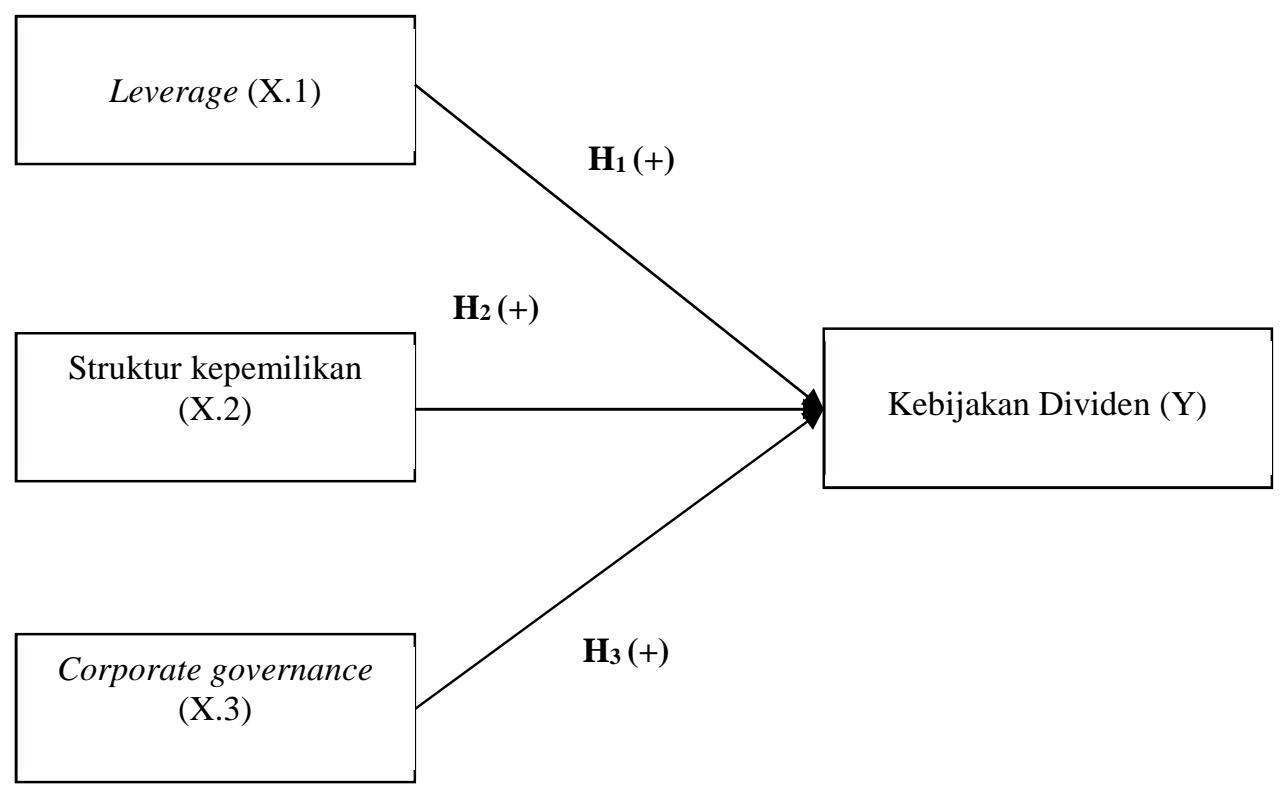

\section{Gambar 1. Kerangka Konseptual}

Sumber: Data Diolah, 2018

\section{METODE PENELITIAN}

Disain penelitian yang dipakai didalam usulan penelitian berikut yaitu pendekatan kuantitatif ataupun positivme yang memiliki bentuk asosiatif, dikarenakan penelitian berikut memiliki tujuan untuk mengetahui bagaimanakah pengaruh variable independent yang dalam penelitian ini adalah leverage, struktur kepemilikan, corporate governance terhadap kebijakan dividen. Diungkapkan kuantitatif sebabnya adalah data yang dipakai adalah data empiris serta variable yang dipakai memiliki satuan yang bisa dilakukan pengukuran. Data yang didapatkan didalam riset berikut dapat diolah serta dilakukan analisis juga 
terdukung adanya kajian pustaka agar dapat memberikan bukti hipotesa juga memberikan jawaban rumusan masalah yang sudah ada sebelum penelitian ini.

Ruang lingkup wilayah penelitian ini dilaksanakan pada semua perusahaanperusahaan manufaktur yang terdaftar di Bursa Efek Indonesia (BEI) periode 20122016 dengan mengakses halaman web dari BEI: www.idx.co.id. Alasan terpilihnya lokasi tersebut dikarenakan saham didalam perusahaan manufaktur mempunyai likuiditas yang besar, nilai kapitalisasi yang tinggi serta termasuk didalam sahamsaham yang mempunyai fundamental juga kinerja yang bagus. Objek daripada penelitian berikut yaitu kebijakan dividen pada sektor manufaktur yang terdaftar di Bursa Efek Indonesia (BEI) tahun 2012-2016. Variabel dalam penelitian ini terdiri dari variabel dependen $(\mathrm{Y})$, variabel independen $(\mathrm{X})$. Variabel dependen dalam penelitian ini adalah kebijakan dividen (Y). Variabel independen dalam penelitian ini adalah leverage $\left(\mathrm{X}_{1}\right)$, struktur kepemilikan $\left(\mathrm{X}_{2}\right)$, corporate governance $\left(\mathrm{X}_{3}\right)$.

Kebijakan Dividen merupakan keputusan manajemen perusahaan terhadap laba yang diproleh perusahaan apakah iklan dibagikan kepada pemegang saham dalam bentuk dividen atau ditahan dalam bentuk laba ditahan. Kebijakan dividen pada penelitian ini diukur dengan dividend payout ratio pada perusahaan manufaktur di BEI peiode 2012-2016. Dividend payout ratio membandingkan dividend per share dengan earning per share dalam satuan persentase.

$$
\begin{aligned}
& D \\
& P
\end{aligned} \quad \text { = } \quad \begin{array}{lll}
d & p & \text { sha } \\
\hline \text { eur } & p & \text { sha }
\end{array}
$$

Leverage yaitu pemakaian asset serta sumber dana (source of funds) oleh organisasi yang mempunyai fix cost dengan tujuan supaya memberikan peningkatan 
pada keuntungan yang memiliki potensi pemilik saham (Sartono, 2008:257). Leverrage yaitu sebuah tingkatan kemampuan orgaisasi didalam memakai aktiva serta juga dana yang memiliki beban tetap (utang) didalam rangka melakukan perwujudan langkah dan tujuan organisasi dalam memaksimalkan kekayaan yang mempunyai organisasi tersebut. Leverrage didalam penelitian ini dihitung dengan Debt to Equity Ratio dapat dihitung dengan rumus yang di kutip dari buku (Wiagustini, 2014:83):

$$
D \quad t_{1} E \quad r_{1}=\frac{T \quad H}{E}
$$

Struktur kepemilikan disimbolkan dengan $\left(\mathrm{X}_{2}\right)$ dalam penelitian ini dinilai dengan melakukan penghitungan presentase saham yang dipunyai oleh manager, dewan direksi serta komisaris pada banyaknya saham beredar di perusahaan perusahaan manufaktur selama periode 2012-2016. Satuan kepemilikan manajemen yaitu persen (\%). Rumus penghitungan kepemilikan manajemen seperti yang dipakai oleh Devi (2017) adalah:

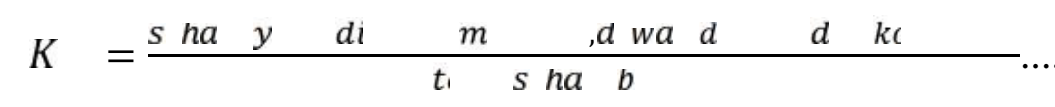

Menurut Reny Dyah Retno \& Denies Priantinah (2012) dalam penerapan Good Corporate Governance diukur dengan menggunakan instrument yang dikembangkan oleh Indonesian Institute for Corporate Governance (IICG) berupa Corporate Governance Perception Index (CGPI) yang diterbitkan di majalah SWA. Penelitian yang dilakukan oleh IICG untuk menilai CGPI (Corporate Governance Perception Index) yaitu setelah melakukan penilaian yang dilakukan dengan cara 
memberi sebuah pemeringkatan yang dilaksanakan dengan cara memberi sebuah nilai pada perusahaan peserta, besar penilaian skor berikut terbuat berdasar kepada acuan yang sudah dibuatkan IICG. Nilai berikut terambil hasilnya berdasar kepada hasil kuisioner penelitian yang diberi langsung ke perusahaan peserta. Berikut ini adalah bobot nilai yang dipakai dalam penilaian GCG (Good Corporate Governance) sebagai berikut:

Tabel 1.

Tahapan dan Bobot Nilai CGPI

\begin{tabular}{clc}
\hline No & \multicolumn{1}{c}{ Indikator } & Bobot (\%) \\
\hline 1 & Self Assessment & 15 \\
2 & Kelengkapan dokumen & 20 \\
3 & Penyusunan makalah dan presentasi & 14 \\
4 & Observasi ke perusahaan & 51 \\
\hline
\end{tabular}

Sumber: CGPI (Corporate Governance Perception Index), 2012

Dari kutipan diatas dapat dijelaskan penilaian proses riset dalam penentuan nilai penerapan corporate governance adalah sebagai berikut: 1) Self Assessment, 2) Kelengkapan dokumen 3) Penyusunan makalah dan presentasi 4) Observasi ke perusahaan. Menurut Corporate Governance Perception Index (CGPI) bahwa nilai CGPI (Corporate Governance Perception Index) dapat menjadi sebuah dasar acuan agar memberikan penentuan perolehan ranking berdasar kepada nilai yang sudah direncanakan sebelumnya. Ringkasan pemeringkat berdasar kepada nilai bisa diberikan penjelasan didalam table berikut ini:

Tabel 2.

Kategori Pemeringkatan CGPI

\begin{tabular}{cc}
\hline Skor & Level Terpercaya \\
\hline $85-100$ & Sangat Terpercaya \\
$70-84$ & Terpercaya \\
$55-69$ & Cukup Terpercaya \\
\hline
\end{tabular}

Sumber: CGPI (Corporate Governance Perception Index), 2012 
Jenis data yang digunakan dalam penelitian ini adalah data kuantitatif, Data kuantitatif dalam penelitian ini adalah data-data mengenai leverage, struktur kepemilikan, corporate governance, kebijakan dividen yang didapatkan dari laporan keuangan tahunan perusahaan manufaktur selama periode 2012-2016 yang terdaftar di BEI. Data yang digunakan dalam penelitian ini adalah data sekunder, Data ini diperoleh dari situs resmi Bursa Efek Indonesia seperti: www.idx.co.id. Populasi dalam penelitian ini adalah seluruh perusahaan manufaktur yg terdaftar di Bursa Efek Indonesia periode 2012-2016. Penelitian berikut dibuat memakai purposive sampling merupakan tehnik menentukan sample dengan memasukkan pertimbangan tertentu. Pertimbangan tertentu yang dimaksud yaitu: 1) Perusahaan manufaktur yang mencantumkan pembagian dividen kepada pemegang saham dalam laporan tahunan pada tahun 2012-2016. 2) Perusahaan manufaktur yg tetap masuk Bursa Efek Indonesia selama 2012-2016.

Sebelum model regresi linier berganda digunakan untuk memprediksi, beberapa peneliti menganggap perlu menguji kelayakan model yang dibuat. Untuk itu dilakukan pengujian asumsi klasik yang meliputi uji normalitas, uji multikolinieritas, uji autokorelasi, dan uji heteroskedastisitas. Statistik deskriptif digunakan untuk mendiskripsi suatu data yang dilihat dari mean, median, deviasi standar, nilai minimum, dan nilai maksimum. Pengujian ini dilakukan untuk mempermudah memahami variabel-variabel yang digunakan dalam penelitian.

Analisis regresi linear berganda (multiple linear regression) digunakan untuk menguji hipotesis yang ada dalam bentuk model persamaan analisis regresi linear berganda sebagai berikut: 


$$
\mathrm{Y}=\alpha+\beta_{1} \mathrm{X}_{1}+\beta_{2} \mathrm{X}_{2}+\beta_{3} \mathrm{X}_{3}+\varepsilon_{1}
$$

Sumber: Wirawan, 2002:293

Keterangan:

$\mathrm{Y}=$ kebijakan dividen

$\alpha=$ konstanta

$\beta_{1} \ldots \beta_{3}=$ koefisien regresi

$\mathrm{X}_{1}=$ leverage

$\mathrm{X}_{2}=$ struktur kepemilikan

$\mathrm{X}_{3}=$ corporate governance

$\varepsilon_{1}=$ koefisien error

\section{HASIL DAN PEMBAHASAN}

Perusahaan yang diteliti adalah perusahaan manufaktur selama 5 tahun, dari 100 perusahaan manufaktur hanya 17 perusahaan yang menjadi sampel penelitian. Banyaknya perusahaan yang secara terus menerus bergabung didalam manufaktur dalam 5 tahun periode 2012-2016 bisa tersaji di table berikut:

Tabel 3. Jumlah Sampel Perusahaan Selama Periode 2012-2016

\begin{tabular}{lll}
\hline No & Keterangan & Jumlah \\
\hline 1 & Perusahaan yang tergabung dalam Sektoral Manufaktur & 147 \\
2 & Perusahaan yang tidak konsisten dalam Sektoral Manufaktur periode 2012 & 108 \\
3 & Perusahaan yang tidak konsisten dalam Sektoral Manufaktur periode 2013 & 69 \\
4 & Perusahaan yang tidak konsisten dalam Sektoral Manufaktur periode 2014 & 48 \\
5 & Perusahaan yang tidak konsisten dalam Sektoral Manufaktur periode 2015 & 32 \\
6 & Perusahaan yang tidak konsisten dalam Sektoral Manufaktur periode 2016 & 18 \\
Jumlah & $\mathbf{1 8}$ \\
\hline
\end{tabular}

Sumber : www.idx.co.id

Tabel 3 memberi petunjuk jumlah perusahaan di sektoral manufaktur yang dijadikan sample didalam penelitian berikut dalam periode 2012-2016. Dari tabel tersebut memberikan petunjuk bahwasannya di tahun 2012 perusahaan yang tak konsisten mengalami pengurangan sebesar 39 perusahaan, di tahun 2013, 2014, 2015 serta 2016 dengan berturut-turut mengalami pengurangan sebesar 39, 21, 16 dan 14 perusahaan yang tak konsisten bergabung didalam sektoral manufaktur. 
Oleh karena itu dari data itu bisa diperleh sample sejumlah 18 perusahaan sektor manufaktur. Hasil daripada uji statistik deskriptif daripada variable leverrage, struktur kepemilikan, serta corporate governance pada kebijakan dividen di sektor manufaktur pada BEI Periode 2012-2016 dapat ditampilkan didalam Tabel dibawah ini:

Tabel 4.

Hasil Uji Statistik Deskriptif

\begin{tabular}{cccccc}
\hline & $\mathrm{N}$ & Minimum & Maximum & Mean & Std. Deviation \\
\hline Leverage & 90 & 0.03 & 0.83 & 0.5111 & 0.17279 \\
Struktur Kepemilikan & 90 & 0.00 & 1.75 & 0.5337 & 0.47878 \\
Corporate Governance & 90 & 78.89 & 100.00 & 91.8641 & 4.84634 \\
Kebijakan Deviden & 90 & 12.47 & 46.87 & 23.6787 & 7.68955 \\
Valid N (listwise) & 90 & & & & \\
\hline
\end{tabular}

Sumber: Data Diolah, 2018

Dari hasil pengujian statistika deskriptif yang tercantum di Tabel 4 diatas, diperoleh suatu informasi sebagai berikut: 1) Variable leverrage mempunyai nilai minimal sebanyak 0,03 nilai maksimal sebanyak 0,83 mean sejumlah 0,51111 , serta standar deviasi sejumlah 0,17279 . Hal berikut ini memiliki arti bahwasannya terdapat perbedaan besaran leverage yang dilakukan penelitian pada nilai rataratanya sejumlah $0,17279.2)$ Variable struktur kepemilikan mempunyai nilai minimum sebanyak 0,00 nilai maksimal sebanyak 1,75 mean senilai 0,5337 , serta standar deviasi sejumlah 0,47878. Hal tersebut memiliki arti bahwasanya adanya perbedaan besaran struktur kepemilikan yang diteliti pada nilai rata-ratanya sebesar 0,47878. 3) Variable good corporate governance mempunyai nilai minimum sebanyak 78,89 nilai maksimum sebanyak 100,00, mean senilai 91,8641, serta standar deviasi sejumlah 4,84634. Hal tersebut mempunyai arti bahwasannya adanya perbedaan nilai good corporate governance yang diteliti terhadap nilai rata- 
ratanya sejumlah 4,84634. 4) Variable kebijakan deviden (Unstandardized Residual) mempunyai nilai minimum sebanyak 12,47 nilai maksimum sebanyak 46,87, mean senilai 23,6787, serta standar deviasi sejumlah 7,68955. Hal tersebut memiliki arti bahwasannya adanya perbedaan kebijakan deviden yang dilakukan penelitian pada nilai rata-ratanya sejumlah 7,68955.

Analisis regresi sangatlah membutuhkan bagian asumsi supaya model bisa dipakai sebagai alat memprediksi yang bagus. Selanjutnya, dilaksanakan uji asumsi classical linear regression model (uji asumsi klasik). Maksud daripada uji asumsi klasik tersebut yaitu agar memberikan kepastian bahwasannya model ataupun persamaan yang dilakukan pengujian tak melakukan pelanggaran asumsi itu. Proses uji ini dilaksanakan agar memberikan bukti bahwasannya hasil yang didapatkan mempunyai sifat BLUE (Best Linear Unbiased Estimator). Proses uji itu diantaranya yaitu multikolonieritas, autokorelasi, heterokorelasi, dan normalitas.

Tabel 5.

Hasil Uji Normalitas

\begin{tabular}{llr}
\hline & & Unstandardized Residual \\
\hline $\mathrm{N}$ & & 90 \\
Normal Parameters ${ }^{\mathrm{a}, \mathrm{b}}$ & Mean & .0000000 \\
& Std. Deviation & 6.91449360 \\
& Absolute & 0.090 \\
Most Extreme Differences & Positif & 0.090 \\
& Negatif & -0.058 \\
Kolmogorov-Smirnov $\mathrm{Z}$ & & 0.851 \\
Asymp. Sig. (2-tailed) & & 0.464 \\
\hline Sumber: Data Diolah, 2018 & &
\end{tabular}

Uji normalitas bertujuan untuk menguji apakah dalam residual dari model regresi yang dibuat berdistribusi normal ataukah tidak. Metode yang digunakan dalam penelitian ini adalah metode statistik Kolmogorov-Smirnov, Alat uji yang biasa disebut K-S ini dapat dilakukan dengan memperhatikan normal probability 
plot juga dengan memperhatikan signifikansi daripada table hasil uji ( $\mathrm{P}>0,05)$. Tabel 5 menunjukkan bahwasannya Nilai Kolmogorov-Smirnov senilai 0,464 serta tingkat signifikannya pada 0,05 (dikarenakan $p=0,464>0.05$ ). Sehingga bias dibuat sebuah kesimpulan bahwasannya residual memiliki distribusi normal. Sebuah model regresi bila memiliki kandungan autokorelasi, jadi prediksi yang dilaksanakan dengan model itu akanlah tak bagus, ataupun bisa memberi sebuah hasil prediksi yang tidak sesuai. Pengujian autokorelasi didalam penelitian berikut dilaksanakan dengan Uji Durbin-Watson (DW-test) ataupun d statistik pada variable pengganggu (disturbance error term).

\section{Tabel 6.}

Hasil Uji Autokorelasi

\begin{tabular}{lccccc}
\hline Model & $\mathrm{R}$ & $\mathrm{R}$ Square & $\begin{array}{c}\text { Adjusted } \mathrm{R} \\
\text { Square }\end{array}$ & $\begin{array}{c}\text { Std. Error of the } \\
\text { Estimate }\end{array}$ & Durbin-Watson \\
\hline 1 & $.228^{\mathrm{a}}$ & .891 & .163 & 7.03406 & 2.143 \\
\hline Sumber $:$ data diolah, 2018 & & & &
\end{tabular}

Pada Tampilan Tabel 6 memberikan petunjuk besarnya nilai Durbin Watson yatiu 2,143. Besaran D-W apabila sesuai dengan tabel yang $n=90$ juga $k=4$ didapatkan nilai $\mathrm{dl}=1.6762$ serta nilai $\mathrm{du}=1.7871$. Dikarenakan nilai $\mathrm{du}<\mathrm{d}<(4-\mathrm{du})$ $(1.7871<2.143<2.2129)$, jadi bisa dibuat kesimpulan tak adanya autokorelasi diantara residual. Uji multikolinearitas bertujuan untuk menguji apakah pada model regresi ditemukan adanya korelasi antar variabel bebas. Model regresi yang baik seharusnya tidak terjadi korelasi di antara variabel bebas. Untuk mendeteksi adanya masalah multikolineritas dapat dilihat dari nilai tolerance dan nilai variance inflation faktor (VIF). Berdasar kepada Tabel 7 bisa terlihat bahwasannya nilai VIF serta Tolerance, yang mana memperlihatkan bahwasanya tak adanya besaran Tolerance yang kurang daripada 0,1 atau nilai VIF yang melebihi daripada 10 . 
Tabel 7.

Hasil Uji Multikolinearitas

\begin{tabular}{llll}
\hline & \multicolumn{1}{c}{ Model } & $\begin{array}{l}\text { Collinearity Statistic } \\
\text { Tolerance }\end{array}$ & VIF \\
\hline 1 & Leverage & 0,910 & 1,099 \\
2 & Struktur kepemilikan & 0,967 & 1,035 \\
3 & Corporate governance & 0,932 & 1,073 \\
\hline
\end{tabular}

Sumber : data diolah, 2018

Oleh dikarenakan hal tersebut berdasar kepada besaran Tolerance serta VIF di model analisa itu tak ditemukannya ada sebuah gejala multikolinearitas. Uji Heteroskedastisitas dilakukan untuk mengetahui bahwa pada model regresi terjadi ketidaksamaan varian. Untuk mendeteksi ada atau tidaknya Heteroskedastisitas digunakan uji model Glejser. Tabel 8 akan memperlihatkan hasil Uji Glejser untuk mendeteksi ada atau tidaknya Heteroskedastisitas.

Tabel 8.

Hasil Uji Heteroskedastisitas

\begin{tabular}{|c|c|c|c|c|c|}
\hline \multirow[t]{2}{*}{ Model } & \multicolumn{2}{|c|}{$\begin{array}{l}\text { Unstandardized } \\
\text { Coefficients }\end{array}$} & \multirow{2}{*}{$\begin{array}{l}\text { Standardized } \\
\text { Coefficients } \\
\text { Beta }\end{array}$} & \multirow[t]{2}{*}{$\mathrm{t}$} & \multirow[t]{2}{*}{ Sig. } \\
\hline & B & Std. Error & & & \\
\hline 1 (Constant) & 0.175 & 8.424 & & -0.021 & 0.984 \\
\hline Leverage & 3.276 & 2.468 & 0.146 & 1.327 & 0.188 \\
\hline Struktur kepemilikan & -1.605 & 0.864 & -0.198 & -1.856 & 0.067 \\
\hline Corporate governance & 0.051 & 0.087 & 0.064 & 0.588 & 0.558 \\
\hline
\end{tabular}

Sumber : data diolah, 2018

Tabel 8 tersebut didapatkan hasil besaran signifikansi $\mathrm{X}_{1}$ sejumlah $0,188, \mathrm{X}_{2}$ sejumlah 0,067 , serta $X_{3}$ senilai 0,558 . Hasil pengujian itu mempunyai nilai yang melebihi daripada $\alpha=0.05$. Dikarenakan hal tersebut, bisa diberikan kesimpulan bahwasannya tak adanya heteroskedastisitas. Analisis regresi linear berganda diolah dengan bantuan software SPSS for Windows dengan hasil yang dapat dilihat pada Tabel 9 dibawah ini. Melihat Tabel 9 tersebut dapat dibuat persamaan sebagai berikut. 


$$
Y=-3,885+4,191 X_{1}+0,383 X_{2}+0,133 X_{3}
$$

Tabel 9.

Rangkuman Hasil Analisis Regresi Linear Berganda

\begin{tabular}{lcllll}
\hline \multirow{2}{*}{ Variabel } & \multicolumn{2}{l}{$\begin{array}{l}\text { Unstandardized } \\
\text { Coefficients }\end{array}$} & $\begin{array}{l}\text { Standardized } \\
\text { Coefficients } \\
\text { Beta }\end{array}$ & $\mathrm{t}$ & \multirow{2}{*}{ Sig } \\
\cline { 2 - 4 } & $\mathrm{B}$ & Std. error & & \\
\hline (Constant) & 65,086 & 15,436 & - & 4,217 & 0,000 \\
Leverage & 9,499 & 4,523 & 0,213 & 2,100 & 0,039 \\
Struktur kepemilikan & 0,737 & 1,584 & 0,046 & 0,465 & 0,043 \\
Corporate governance & 0,508 & 0,159 & 0,320 & 3,186 & 0,002 \\
$\mathrm{R}^{2}$ Square & $: 0,891$ & & & & \\
F Hitung & $: \quad 6,787$ & & & & \\
Sig F & $: 0,000$ & & & &
\end{tabular}

Berdasarkan persamaan di atas, dapat dijelaskan hal-hal seperti berikut. 1)

Nilai konstanta sejumlah 65,086, bila besaran leverage $\left(\mathrm{X}_{1}\right)$, struktur kepemilikan $\left(\mathrm{X}_{2}\right)$, serta good corporate governance $\left(\mathrm{X}_{3}\right)$ sama dengan nol, jadi nilai Kebijakan Deviden (Y) tak mengalami peningkatan ataupun sama dengan 65,086 satuan. 2) $\beta_{1}$ $=9,499$, apabila nilai leverage $\left(X_{1}\right)$ mengalami penambahan 1 satuan, jadi nilai daripada kebijakan deviden (Y) akanlah mngalami penambahan sejumlah 9,499 satuan dengan asumsi variable independen lain kontan. 3) $\beta_{2}=0,737$, bila nilai struktur kepemilikan $\left(\mathrm{X}_{2}\right)$ mengalami penambahan 1 satuan, jadi nilai daripada kebijakan deviden (Y) akanlah mengalami pengurangan sejumlah 0,737 satuan dengan asumsi variable independen lain konstan. 4) $\beta_{3}=0,508$, bila good corporate governance $\left(\mathrm{X}_{3}\right)$ mengalami penambahan 1 satuan, jadi nilai dari nilai kebijakan deviden (Y) akanlah mengalami penambahan sebesar 0,508 satuan dengan asumsi variable independen lain konstan.

Hasil pengujian $\mathrm{F}$ ( $F$ test) memberikan petunjuk bahwasannya nilai $\mathrm{F}$ hitung sejumlah 19,152 dengan besaran signifikansi $\mathrm{P}$ value 0,000 yang lebih rendah daripada $\alpha=0,05$, hal tersebut mempunyai arti model yang dipakai di penelitian 
berikut menjadi layak. Hasil tersebut memberi pemaknaan bahwasannya ketiga variable bebas mampu melakukan prediksi ataupun memberi penjelasan kejadian kebijakan deviden pada sektor manufaktur yang ada di BEI Periode 2012-2016. Hal tersebut memiliki arti bahwasannya model bisa dipakai dalam penganalisaan lebih lanjut ataupun dengan lain kata model bisa dipakai sebagai representatif dikarenakan hasil goodness of fitnya bagus dengan nilai $\mathrm{F}$ hitung sejumlah 6,787 dengan nilai signifikan $\mathrm{P}$ value 0,000 .

Mengetahui serta melakukan pengukuran mampun atau tidaknya model didalam memberikan penerangan variasi variable bebas menggunakan koefisien determinasi $\left(\mathrm{R}^{2}\right)$. Peneliti memakai nilai $\mathrm{R}^{2}$ di kala melakukan evaluasi dimana model regresi terbagus, dikarenakan nilai $\mathrm{R}^{2}$ bisa mengalami kenaikan ataupun penurunan bila suatu variable bebas dilakukan penambahan kedalam model. Hasil pengujian memberi hasil yang mana didapatkan besaran nilai $\mathrm{R}^{2}$ (koefisien determinasi yang sudah disesuaikan) di Tabel 9 yaitu 0,891 . Hal berikut memiliki arti variasi nilai kebijakan deviden bisa terpengaruh dengan signifikan dengan adanya variable leverrage, struktur kepemilikan, serta corporate governance sebesar 89,1 persen, namun sisanya dapat dijelaskan faktor-faktor lain.

Hasil perhitungan uji t dapat dilihat pada tabel 9. Dari tabel tersebut didapatkan bahwasannya nilai koefisien regresi $\mathrm{X}_{1}$ ataupun leverage yaitu sejumlah 2,100 dengan tingkat signifikansi senilai 0,039 kurang dari taraf nyata $\alpha=0,05$. Hal tersebut memberikan petunjuk bahwasannya leverage memiliki pengaruh positif serta signifikan pada kebijakan deviden. Jadi hipotesa yang memberi pernyataan bahwasannya leverage memiliki pengaruh positif serta signifikan terhadap 
kebijakan deviden pada perusahaan manufaktur dala BEI periode 2012-2016 diterima. Hasil perhitungan uji t dapat dilihat pada tabel 9. Dari tabel tersebut diketahui bahwa nilai koefisien regresi $\mathrm{X}_{2}$ atau struktur kepemilikan adalah 0,465 dengan tingkat signifikans senilai 0,043 kurang daripada taraf nyata $\alpha=0,05$. Hal tersebut memberikan petunjuk bahwasannya struktur kepemilikan memiliki pengaruh positif serta signifikan pada kebijakan dividen di perusahaan manufaktur dalam BEI periode 2012-2016. Jadi hipotesis yang memberi pernyataan bahwasannya struktur kepemilikan memiliki pengaruh positif serta signifikan pada kebijakan deviden pada perusahaan manufaktur di Bursa Efek Indonesia Periode 2012-2016 diterima.

Hasil perhitungan uji t dapat dilihat pada tabel 9. Dari tabel tersebut diketahui bahwa besaran koefisien regresi $X_{3}$ ataupun good corporate governance yaitu sejumlah 3,186 dengan tingkat signifikans senilai 0,002 kurang daripada taraf nyata $\alpha=0,05$. Hal tersebut memberi petunjuk bahwasannya good corporate governance memiliki pengaruh positif serta signifikan pada kebijakan dividen untuk perusahaan manufaktur dalam BEI Periode 2012-2016. Jadi hipotesa yang memberikan pernyataan bahwasannya good corporate governance memiliki pengaruh positif serta signifikan pada kebijakan deviden pada perusahaan manufaktur dalam BEI Periode 2012-2016 diterima.

Hasil analisis regresi memberikan petunjuk bahwa leverrage secara statistik memiliki pengaruh positif serta signifikan pada kebijakan deviden $\left(\mathrm{H}_{1}\right.$ diterima $)$. Menurut Brigham (2011) makin besarnya leverrage perusahan jadi memiliki kecenderungan dalam pembayaran devidennya lebih kecil dengan maksud agar 
A A Istri Alit Urmila Dewi, Pengaruh Leverage...

memberikan pengurangan rasa bergantung untuk dana yang didapatkan dari pihak luar perusahaan. Hal ini membuat makin tingginya rasio utang yang dipakai dalam struktur modal sebuah perusahaan, jadinya akanlah makin tinggi juga besaran kewajibannya yang dapat memberikan pengaruh tinggi rendahnya deviden yang dapat terbagi.

Hasil penelitian ini didukung oleh Penelitian Mossadak dan Khemakhem (2015) mendapatkan bahwasannya hubungan negatif serta signifikan diantara tingkat utang dengan kebijakan deviden. Hal berikut memiliki perbandingan dengan penelitian yang dilaksanakan oleh Devi (2017) yang tak mendapatkan pengaruh signifikan diantara leverrage dengan kebijakan dividen. Indah et al. (2010) menemukan pengaruh signifikan positif antara leverage dengan kebijakan dividen. Tina (2017) menyatakan pengaruh signifikan positif variabel leverage dengan kebijakan dividen.

Hasil analisis regresi memberikan petunjuk bahwasannya struktur kepemilikan dengan statistik memiliki pengaruh positif serta signifikan pada kebijakan dividen $\left(\mathrm{H}_{2}\right.$ diterima). Hal tersebut memberikan petunjuk makin tingginya persentase kepemilikan managerial sebuah perusahaan jadi makin tinggi pula deviden yang terbagikan untuk para investor dikarenakan makin tingginya persentase kepemilikan managerial dapat makin tinggi juga mampu atau tidaknya memperoleh keuntungan, dikarenakan selain manajer tersebut mengurus saham investor, manager itu pula mengurus saham mereka sendiri jadi deviden yang terbagi pada investor pun besar (Devi, 2017). 
Hal ini didukung oleh penelitian yang dilakukan oleh Kulathunga dan Azeez (2015) memberi pernyataan bahwasannya hubungan diantara kepemilikan manajerial dengan kebijakan dividen dengan signifikan memiliki hubungan positif. Penelitian oleh Ikunda dan Kamau (2016) menyatakan bahwa struktur kepemilikan individu dan struktur kepemilikan institusional tidak memiliki hubungan signifikan terhadap dividend payout, serta terdapat korelasi positif antara struktur kepemilikan asing dan pembayaran dividen. Penelitian Ekanayake dan Paranthaman (2015) kepemilikan manajerial berpengaruh positif dan signifikan terhadap kebijakan dividen di Indonesia. Sedangkan kepemilikan institusional memiliki pengaruh positif dan signifikan dalam penelitian yang dilakukan oleh Ayu dan Vinola (2017).

Hasil analisis regresi menunjukan bahwasannya good corporate governance secara statistik memiliki pengaruh positif serta signifikan terhadap kebijakan deviden ( $\mathrm{H}_{3}$ diterima). Anggie (2013) mencatat bahwa tata kelola perusahaan yang efisien dapat memberikan checks and balances antara manajer dan pemegang saham dan ini bisa membuat perusahaan untuk mengadopsi kebijakan dividen yang memaksimalkan kekayaan pemegang saham.

Hal ini didukung oleh penelitian yang dilakukan oleh Ikunda (2016) menemukan bahwa good corporate governance memiliki pengaruh positif dan signifikan pada kebijakan dividen. Indah et al. (2010) memberikan bukti bahwasannya good corporate governance memiliki pengaruh positif pada kebijakan dividen. Putri (2018) memberikan pernyataan bahwasannya variable good corporate governance memiliki pengaruh positif dan signifikan terhadap kebijakan dividen di dalam perusahaan. Tina (2017) membuktikan hal yang sama 
dimana variabel $G C G$ memiliki pengaruh positif signifikan terhadap kebijakan dividen.

Adapun beberapa keterbatasan dala penelitian ini adalah, 1) Penelitian ini hanya menggunakan perusahaan sektoral manufaktur di Bursa Efek Indonesia, sedangkan masih terdapat beberapa perusahaan lainnya yang terdaftar di Bursa Efek Indonesia. 2) Penelitian hanyalah memakai tehnik analisis regresi linear berganda, sedangkan bisa berkembang lagi dengan teknik analisis yang lain, contohnya: path analisis, SEM analisis, serta AMOS. 3) Penelitian memperlibatkan subjek yang memiliki batas, yaitu 18 perusahaan dengan periode yang terbatas hanya 2012-2016, hingga hasil tidak bisa menggeneralisasikan di kelompok subjek dengan jumlah besar.

\section{SIMPULAN DAN SARAN}

Berdasarkan pada hasil analisis data dan pembahasan yang telah dipaparkan pada bab sebelumnya, maka dapat ditarik kesimpulan sebagai berikut : 1) Leverage secara signifikan berpengaruh positif terhadap kebijakan deviden sektoral manufaktur di BEI periode tahun 2012-2016. Ini berarti peningkatan hutang akan memengaruhi besar kecilnya laba bersih yang tersedia bagi para pemegang saham termasuk dividen yang akan diterima. 2) Struktur kepemilikan secara signifikan berpengaruh positif terhadap kebijakan deviden sektoral manufaktur di Bursa Efek Indonesia periode tahun 2012-2016. Hal ini memberi petunjuk makin besarnya presentase kepemilikan manajerial sebuah organisasi jadi makin tinggi dividen yang dibagikan kepada pemegang saham dikarenakan makin tiggi persentase kepemilikan manajerial. 3) Good corporate governance secara signifikan 
berpengaruh positif terhadap kebijakan deviden sektoral manufaktur di Bursa Efek Indonesia periode tahun 2012-2016. Hal ini menunjukkan tata kelola perusahaan yang efisien dapat memberikan checks and balances antara manajer dan pemegang saham dan ini bisa membuat perusahaan untuk mengadopsi kebijakan dividen yang memaksimalkan kekayaan pemegang saham.

Adapun saran yang dapat diberikan adalah, 1) Hasil dari penelitian ini dapat dijadikan refrensi untuk menambah bukti empiris pada manajemen keuangan mengenai pengaruh leverage, struktur kepemilikan serta good corporate governance terhadap kebijakan deviden sektoral manufaktur di BEI periode tahun 2012-2016. 2) Perusahaan sektoral manufaktur diharapkan memperhatikan peningkatan hutang yang akan memengaruhi besar kecilnya laba bersih yang tersedia bagi para pemegang saham termasuk dividen yang akan diterima. Makin tingginya leverage organisasi jadi cenderung agar membayar dividennya lebih kecil dengan tujuan agar mengurangi rasa tergantung di pendanaan secara eksternal. Sehingga makin besar proporsi hutang yang dipakai untuk struktur modal suatu perusahaan, maka akan semakin besar pula jumlah kewajibannya yang akan memengaruhi besar kecilnya dividen yang akan dibagikan. 3) Peran struktur kepemilikan sangat penting pengaruhnya terhadap kebijakan perusahaan, makin tinggi dividen yang terbagi pada pemegang saham dikarenakan makin tinggi persentase kepemilikan manajerial akan makin tinggi pula kemampuan menghasilkan laba. 4) Penerapan good corporate governance sebagai tata kelola perusahaan bertujuan untuk melindungi kepentingan pemegang saham dengan 
mengurangi masalah keagenan dan oleh karena itu, kebijakan dividen menjadi aspek penting dari tata kelola perusahaan.

\section{REFERENSI}

Agoes, Sukrisno. (2014). Auditing Petunjuk Praktis Pemeriksaan Akuntan oleh Akuntan Publik. Edisi ke 4. Buku 1. Jakarta: Salemba Empat

Anggie Noor Rachmad. (2013). Pengaruh Struktur Kepemilikan, Leverage, dan Return on Assets (ROA) terhadap Kebijakan Dividen (Studi Empiris pada Perusahaan Nonkeuangan yang Terdaftar di Bursa Efek Indonesia). Diponegoro Jurnal of Acounting. 2(3): pp: 1-11

Anuar., Yakob. (2014). The Impact of Profitability, liquidity, leverage, and Firm Size on Cash Dividend Payments For Public Listed Companies in Malaysia and Thailand. The Global Journal of Finance and Economics. 11 (2): pp: 101-129.

Ayu Dwi, Hasty., Vinola, Herawaty. (2017). Pengaruh Struktur Kepemilikan, Leverage, Profitabilitas, dan Kebijakan Dividen Terhadap Manajemen Laba dengan Kualitas Audit sebagai variabel Moderasi. Jurnal Media Riset Akuntansi, Auditing \& Informasi. 17(1): h: 1-16

Ballagobei dan Thiruchchenthurnathan. (2016). Impact of Ownership Structure on Dividend Payout Policy: An Empirical Study on Listed Plantation Companies in Sri Lanka. Research Journal of Finance and Accounting Faculty of Management Studies and Commerce, University of Jaffna. 7 (14): pp: 93-98.

Brigham, E. F. Gapenski, L. C. (2011). "Intermediate Finance Management" (5th ed.). Harbor Drive: The Dryden Press.

Ekanayake dan Paranthaman. (2015). The Impact Of Corporate Governance On Firms' Dividend Policy: Evidence From The Listed S\&P S120 Companies In The Colombo Stock Exchange. Department of Commerce, Faculty of Commerce and Management, Eastern University, Sri Lanka. 4(1): pp: 116.

Ghozali, Imam, (2012), Aplikasi Analisis Multivariat/2, Badan Penerbit Undip, Semarang

Ikunda, Muiru dan Kamau. (2016). The Impact of Corporate Governance on Dividend Payout of Manufacturing Firms Listed at the Nairobi Securities Exchange. Journal of Finance and Accounting Egerton University. 4 (5): pp: $254-261$ 
Indah Sulistiyowati, Ratna Anggraini, Tri Hesti Utaminingtyas. (2010). Pengaruh Profitabilitas, Leverage, dan Growth Terhadap Kebijakan Dividen dengan Good Corporate Governance sebagai Variabel Intervening. Jurnal Simposium Nasional Akuntansi. 4(1): h: 1-23

Kulathunga dan Azeez. (2015). The Impact Of Ownership Structure On Dividend Policy: Evidence From Listed Companies In Sri Lanka. Research Gate, Department of Finance- Faculty of Commerce and Management Studies University of Kelaniya. 3 (1): pp: 34-42

Mossadak, Fontaine dan Khemakhem. (2015). The Relationship between Ownership Structure and Dividend Policy in an Emerging Market: A Moroccan Study. Universal Journal of Accounting and Finance University of Quebec in Montreal, Canada. 4(2): pp: 89-95.

Muhammad Akhyar Adnan Ratri Candrasar. (2015). Pengaruh Profitabilitas, Leverage, Growth, dan Free Cash Flow terhadap Dividend Payout Ratio Perusahaan Dengan mempertimbangkan Corporate Governance Sebagai Variabel Intervening. Jurnal Ekonomi dan Bisnis. 4(1): h: 1-12

Osman dan Mohammed. (2010). Dividend Policy In Saudi Arabia. The International Journal of Business and Finance Research Dialdin Osman, Tougaloo College. 4 (1): pp: 99-113.

Putri Octiani Maralinda. (2018). Pengaruh Financial Leverage, Mekanisme Good Corporate Governance, Kepemilikan Publik, dan Ukuran Perusahaan, Terhadap Praktek Perataan Lapangan. Jurnal Manajemen Akuntansi. 3(1): h: $1-25$

Sartono, A. (2012). Manajemen Keuangan Teori dan Aplikasi.Edisi ke empat. Yogyakarta: BPFE.

Sartono, Agus. (2008). Manajemen Keuangan: Teori dan Aplikasi. Edisi Keempat. Yogyakarta: BPFE

Scott, William R. (2003). Financial Accounting Theory. New Jersey : Prentice Hall Inc

Sugiyono. (2013). Metode Penelitian Kuantitatif Kualitatif dan R\&D. Bandung: Penerbit Alfabeta.

Tina Rosaline Megawati Oktorina. (2017). Analisis Pengaruh Leverage, Set Kesempatan Investasi, Kepemilikan Manajerial, dan Corporate Governance terhadap Kebijakan Dividen. Jurnal Ekonomi dan Bisnis. 2(6): h: 138-151

Vo dan Nguyen. (2014). Managerial Ownership, Leverage and Dividend Policies: Empirical Evidence from Vietnam's Listed Firms. International 
A A Istri Alit Urmila Dewi, Pengaruh Leverage...

Journal of Economics and Finance, Published by Canadian Center of Science and Education. 6 (5): pp: 274-284.

Wiagustini, Ni luh Putu. (2010). Dasar-Dasar Manajemen Keuangan. Denpasar. Udayana University Press. 